\title{
Longkankerrisico en blootstelling aan cadmium via het milieu: antwoord op de kritiek met toetsing van de causaliteit
}

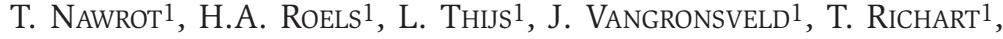 \\ E. VAN HeCKe 1 , J.A. STAESSEN 1,2
}

\section{Samenvatting}

Wij onderzochten of het risico van longkanker in verband staat met blootstelling aan cadmium via het leefmilieu. Daartoe werden 994 personen gerekruteerd door middel van een aselecte steekproef in gebieden met een hoge en een lage blootstelling aan cadmium. In de periode 1985-1989 maten wij bij deze proefpersonen de hoeveelheid cadmium die gedurende 24 uur via de urine werd uitgescheiden (een index van de levenslange blootstelling), evenals de cadmiumconcentratie in de bodem van hun moestuintjes. We volgden de cohorte tot oktober 2004.

De cadmiumconcentratie in de bodem had een bereik van 0,8 tot $17,0 \mathrm{mg} / \mathrm{kg}$. De gemiddelde cadmiumuitscheiding gedurende 24 uur bedroeg $12,3 \mathrm{nmol}$ bij de proefpersonen in het verontreinigde gebied tegen $7,7 \mathrm{nmol}$ per dag in het referentiegebied $(p<0,0001)$. Over 17,2 jaar (mediaan) kregen 53 deelnemers kanker met dodelijke afloop en 20 een niet-fatale neoplastische aandoening (resultaten geactualiseerd tot 31 oktober 2004). Hieronder waren 18 patiënten met dodelijke longkanker en 1 patiënt die een longkanker overleefde.

In veelvoudig aangepaste analysen, waarbij rekening gehouden werd met geslacht, leeftijd en rookgewoonten, steeg het risico op longkanker met 70\% (95\%-betrouwbaarheidsinterval: 13-157\%) voor iedere verdubbeling van de hoeveelheid cadmium uitgescheiden via de urine. Het longkankerrisico was 4,2 maal (1,2$14,4)$ hoger in het verontreinigde gebied dan in het referentiegebied, en het steeg met $57 \%(11-124 \%)$ per verdubbeling van de cadmiumconcentratie in de bodem.

In dit artikel stellen wij eerst een korte samenvatting voor van de eerder in het Engels gepubliceerde resultaten. Vervolgens rapporteren wij de resultaten van bijkomende analysen, die wij uitvoerden naar aanleiding van kritiek op onze primaire studie. Hierbij toetsen we onze oorspronkelijke en bijkomende studieresultaten aan de Bradford-Hill-criteria voor een oorzakelijk verband.

We geven voorts een overzicht van de mogelijke mechanismen, waarbij cadmium van het leefmilieu overgaat naar de mens, en van de preventiemaatregelen die in met cadmium vervuilde gebieden genomen kunnen worden.

\section{Inleiding}

Het toxische metaal cadmium wordt na inhalatie of ingestie in het lichaam opgenomen en gedeeltelijk weer uitgescheiden via de nieren. De eliminatiehalfwaardetijd bedraagt 20 tot 30 jaar. In een transversaal bevolkingsonderzoek, dat onder de naam „Cadmium in Belgium” (CadmiBel) van 1985 tot 1989 plaatsvond in België, toonden we aan dat inwoners van gebieden met een historische cadmiumverontreiniging, zoals de Noorderkempen en Luik, een lichaamsbelasting met dit metaal hebben, die

1 Studiecoördinatiecentrum, Laboratorium Hypertensie, K.U.Leuven.

2 Correspondentieadres: dr. J.A. Staessen, Studiecoördinatiecentrum, Laboratorium Hypertensie, Campus Gasthuisberg, Herestraat 49, bus 702, 3000 Leuven; e-mail: jan.staessen@med.kuleuven.be gemiddeld $30 \%$ hoger is dan in minder vervuilde gebieden, zoals Hechtel-Eksel en Charleroi. De hogere lichaamsbelasting geeft aanleiding tot tubulaire nierfunctiestoornissen met microproteïnurie en hypercalciurie, met osteoporose en een verhoogde incidentie van fracturen tot gevolg (1-3).

Het International Agency for Research on Cancer (IARC) klasseerde in 1993 cadmium als een carcinogeen gebaseerd op de resultaten van epidemiologisch onderzoek bij arbeiders en dierproefstudies (4). Inderdaad vonden Verougstraete et al. in een meta-analyse van de vijf belangrijkste studies van aan cadmium blootgestelde arbeiders een oversterfte met $20 \%$ ten gevolge van longkanker (5). In experimenteel onderzoek werd voorts aangetoond dat al zeer lage cadmiumconcentraties, van een grootteorde van 0,9 tot $6 \mu \mathrm{M}$, het DNAherstelsysteem („mismatch repair”) verstoren $(6,7)$. Deze bevindingen en het ontbreken van elk prospectief 
bevolkingsonderzoek over de mogelijke carcinogeniteit van cadmium bij mensen die uitsluitend via het leefmilieu blootgesteld waren, leidden tot de wetenschappelijke ratio van onze studie, die in februari 2006 in The Lancet Oncology gepubliceerd werd (8).

Onze onderzoeksresultaten brachten een toename van het longkankerrisico in een met cadmium verontreinigde regio in verband met de uitwendige blootstelling via het leefmilieu, alsook met de inwendige lichaamsbelasting, zoals weerspiegeld door biomarkers. Onze bevindingen doorstonden het strenge expertrevisieproces van een toonaangevend medisch vakblad als The Lancet. Nochtans leverden enkele Vlaamse wetenschappers scherpe kritiek op onze studie, echter niet op de wetenschappelijk gangbare manier, bijvoorbeeld door een brief naar de redactie van The Lancet Oncology te sturen, maar via de openbare massamedia.

Met dit artikel hopen we op deze kritiek te mogen antwoorden in een Nederlandstalig medisch vakblad. Hierbij zullen wij de bijkomende gegevens voorstellen, die we in antwoord op de kritiek gegenereerd hebben. We zullen tevens onze onderzoeksresultaten toetsen aan de criteria voorgesteld door Bradford-Hill om op basis van epidemiologisch onderzoek causaal verband te kunnen aantonen (9-11).

\section{De metaalindustrie in het noordoosten van Vlaanderen}

Wij voerden ons bevolkingsonderzoek uit in een landelijk gebied in het noordoosten van Vlaanderen in een regio met een historische verontreiniging met zware metalen, in het bijzonder cadmium en zink. De industriële vervuiling startte op het einde van de 19de eeuw en duurde voort tot omstreeks 1980.

Onze studie greep plaats in zes wijken met een verontreinigde bodem, die in de omgeving van de vroegere metaalbedrijven gelegen zijn, namelijk Balen-Wezel, MolWezel, Lommel-Werkplaatsen, Lommel-Barrier, OverpeltFabriek en Neerpelt-Heide. Vóór 1975 gebruikten de zinkfabrieken van Lommel en Overpelt een zeer vervuilend pyrometallurgisch productieproces. De fabriek in Balen gebruikte echter hoofdzakelijk een elektrolytisch procedé voor de productie van zink en cadmium. De zinkfabriek van Lommel sloot in 1974. In het begin van de jaren tachtig schakelde het bedrijf te Overpelt eveneens over op elektrolyse. In het begin van de jaren negentig stopte de productie van zink en cadmium te Overpelt en in januari 2002 die van cadmium te Balen.

Wij onderzochten ook de bevolking van een controlegebied op grotere afstand van de smelters, dat minder met cadmium besmet werd en uit vier wijken bestond, namelijk: Eksel-Kern, Eksel-Locht, Hechtel-Kern en Hechtel-Rest.

\section{Identificatie van de steekproef van de bevolking}

De 1.107 Vlaamse deelnemers aan het transversale onderzoek, uitgevoerd van 1985 tot 1989, vertegenwoordigden een door loting aangewezen steekproef van de bevolking van de bovenvermeldde 10 wijken. Vertrekkend van de bevolkingslijsten identificeerden we een gezin als alle personen die een gemeenschappelijk adres hadden. Het toeval wees aan welke gezinnen we voor het onderzoek moesten uitnodigen. We verdeelden het staal in geledingen volgens geslacht en leeftijd (20-39, 40-59, $\geq 60$ jaar) met het doel evenveel deelnemers te rekruteren in ieder van de zes strata. We nodigden alle gezinsleden met een leeftijd van 20 jaar of meer uit, op voorwaarde dat ze minstens 8 jaar aaneensluitend in de regio verbleven hadden en op voorwaarde dat het quotum van hun geleding nog niet bereikt was. De gelede staaltrekking garandeerde een gelijke verdeling van geslacht en leeftijd in alle wijken.

De deelnemers vulden een omstandige vragenlijst in, verzamelden een 24 uursurinestaal en ondergingen een bloedname. In onze vroegere publicaties beschreven we de biochemische methodiek en kwaliteitscontroles (12, 13). We schatten levenslange blootstelling aan cadmium aan de hand van de urinaire uitscheiding over 24 uur. We bemonsterden op 10 verschillende plaatsen de toplaag van de moestuinen van de deelnemers op diepten variërend van 0 tot $25 \mathrm{~cm}$. Deze 10 grondstalen werden na droging gemengd voor bepaling van de cadmiumconcentratie.

Via het Rijksregister te Brussel controleerden we de vitale status van alle deelnemers tot 31 oktober 2004. We raadpleegden de Vlaamse overlijdensstatistieken om de doodsoorzaak te kennen. Bij de opvolging van de deelnemers, hetzij aan huis, hetzij in ons onderzoekscentrum te Eksel, gebruikten we dezelfde gevalideerde vragenlijst als deze afgenomen bij de rekrutering, om informatie te verzamelen over niet-fatale eindpunten. Voor zo ver mogelijk, verifieerden we systematisch alle diagnosen vermeld op het overlijdenscertificaat of in de vragenlijsten tegen de medische dossiers van huisartsen of ziekenhuizen.

\section{Samenvatting van onze bevindingen gepubliceerd in The Lancet Oncology}

De 521 deelnemers die woonden in de verontreinigde wijken, hadden een hogere uitscheiding van cadmium (tabel 1) en arsenicum (8) in de urine en een wat lagere socio-economische achtergrond dan de 473 personen gerekruteerd in het controlegebied. Overigens hadden de inwoners van het vervuilde en het controlegebied gelijke kenmerken. De urinaire cadmiumuitscheiding over 24 uur nam toe met de leeftijd met 2,59 nmol per decennium ( $<<0,001$ ). De verhouding rokers was gelijk in alle wijken. Bij 224 mannelijke rokers bedroeg de mediaan van het dagelijkse tabaksverbruik 17 sigaretten (25-75ste centiel: 11-24). Bij 165 rokende vrouwen was de mediaan 15 sigaretten per dag (10-20). Onder de deelnemers aan het onderzoek waren er 42 werknemers $(9 \%)$ van wie de arbeidsgeneeskundige kon bevestigen dat zij op basis van hun activiteit binnen het bedrijf mogelijkerwijze waren blootgesteld aan cadmium. 
TABEL 1

Kenmerken van de studiebevolking.

\begin{tabular}{|c|c|c|c|}
\hline Kenmerk & $\begin{array}{l}\text { Referentiegebied } \\
\qquad(n=473)\end{array}$ & $\begin{array}{l}\text { Vervuild gebied } \\
\qquad(n=521)\end{array}$ & $\mathbf{p}$ \\
\hline Vrouwen (\%) & $257(54,3)$ & $266(51,1)$ & 0,30 \\
\hline Mediane leeftijd (bereik) & $45,6(19,8-91,0)$ & $46,8(19,9-87,5)$ & 0,95 \\
\hline Ex-rokers (\%) & $98(20,7)$ & $120(23,0)$ & 0,37 \\
\hline Rokers (\%) & $178(37,6)$ & $211(40,5)$ & 0,36 \\
\hline Beroepsmatige blootstelling (\%) & $3(0,6)$ & $39(7,5)$ & $<0,0001$ \\
\hline \multicolumn{4}{|l|}{ Gemiddelde (SD) creatinine } \\
\hline Serumconcentratie $(\mu \mathrm{mol} / \mathrm{l})$ & $97,8(24,1)$ & $101,2(18,5)$ & 0,017 \\
\hline Urinaire uitscheiding (mmol/dag) & $12,1(3,9)$ & $12,3(4,4)$ & 0,59 \\
\hline \multicolumn{4}{|c|}{ Meetkundig gemiddelde blootstelling (25-75e centiel) } \\
\hline Afstand tot de smelter (km) & $10,7(9,7-12,6)$ & $1,12(1,06-1,18)$ & $<0,0001$ \\
\hline Cadmiumgehalte in de bodem (mg/kg) & $0,81(0,79-0,88)$ & $7,97(7,75-8,21)$ & $<0,0001$ \\
\hline Cadmium in het bloed $(\mathrm{nmol} / \mathrm{l})$ & $10,5(5,4-11,8)$ & $11,9(11,2-12,8)$ & 0,0061 \\
\hline Cadmiumuitscheiding (nmol/dag) & $7,7(7,3-8,2)$ & $12,3(11,5-13,2)$ & $<0,0001$ \\
\hline
\end{tabular}

p-waarden voor de vergelijking tussen het vervuild en het referentiegebied zijn gebaseerd op de z-toets voor grote steekproeven (gemiddelden) en de fisherexacttest (verhoudingen).

Tijdens het vervolgonderzoek dat gemiddeld (mediaan) over 17,2 jaar liep, kregen 53 deelnemers een dodelijk verlopende kanker en kregen 20 een niet-fatale neoplastische aandoening (gegevens geactualiseerd van 30 juni 2004 tot 31 oktober 2004). Hierbij waren 19 patiënten met longkanker, met een dodelijke afloop bij 18 (fig. 1 en 2). De longkankerincidentie in de risicoen referentiegebieden bedroeg respectievelijk 1,80 en 0,38 gevallen per 1.000 persoonsjaren. De kans dat toeval dit verschil zou kunnen verklaren, bedraagt 1,6\% $(\mathrm{p}=0,016)$.

Meervoudige testprocedures, waarbij we rekening hielden met verstrengelende factoren aanwezig op de basislijn, waaronder geslacht, leeftijd en ooit gerookt te hebben, bevestigden de significante associatie tussen het longkankerrisico en de urinaire cadmiumuitscheiding over 24 uur. Rekening houdend met deze verstrengelende factoren, toonden wij ook significante relaties aan tussen longkanker enerzijds en de cadmiumconcentratie in de bodem of wonen in het verontreinigde gebied anderzijds. Het longkankerrisico was in het vervuilde gebied 4,17 maal hoger dan in de referentiegemeente. Het 95\%-betrouwbaarheidsinterval $(95 \%-\mathrm{BI})$ reikte van 1,21 tot $14,4(\mathrm{p}=0,024)$. Deze resultaten bleven onverkort overeind, wanneer we onze berekeningen aanpasten voor het aantal pakjaren sigaretten of voor roken op de basislijn in plaats van ooit roken, of voor de duur dat eerdere rokers gestopt waren met tabaksgebruik.

Van de 42 mannen met professionele cadmiumblootstelling kregen vier longkanker en vier kankers van andere organen. Met leeftijd en rookgewoonte in rekening gebracht, hadden deze arbeiders een 3,2 maal hoger longkankerrisico in vergelijking met mannen uitsluitend blootgesteld via het leefmilieu. Het 95\%-BI ging van 1,0 tot $10,8(\mathrm{p}=0,05)$.

\section{Resultaten gegenereerd als antwoord op de kritische commentaren}

\section{Kritiek}

Er is onvoldoende rekening gehouden met rookgewoonten en geen rekening gehouden met veranderingen in rookgewoonten tijdens de opvolgperiode.

\section{Antwoord}

In onze gepubliceerde analysen hielden we, zoals hierboven beschreven, rekening met roken op vier verschillende wijzen. In alle gevallen bleef het verband tussen longkanker en de cadmiumblootstelling behouden. Bovendien menen we, op basis van volgende bijkomende argumenten, dat het niet aannemelijk is dat roken de opgetekende associaties kan verklaren.

Rookgewoonten, gemeten aan de hand van de prevalentie van ooit roken of huidig roken of op basis van het aantal pakjaren sigaretten, verschilden helemaal niet tussen het verontreinigde en het controlegebeid. Nochtans was de urinaire cadmiumexcretie $60 \%$ hoger in het vervuilde gebied. Roken verhoogde de cadmiumuitscheiding maar met $24 \%$. Het woongebied was daarom een belangrijkere determinant van de urinaire cadmiumuitscheiding dan de rookgewoonte. 


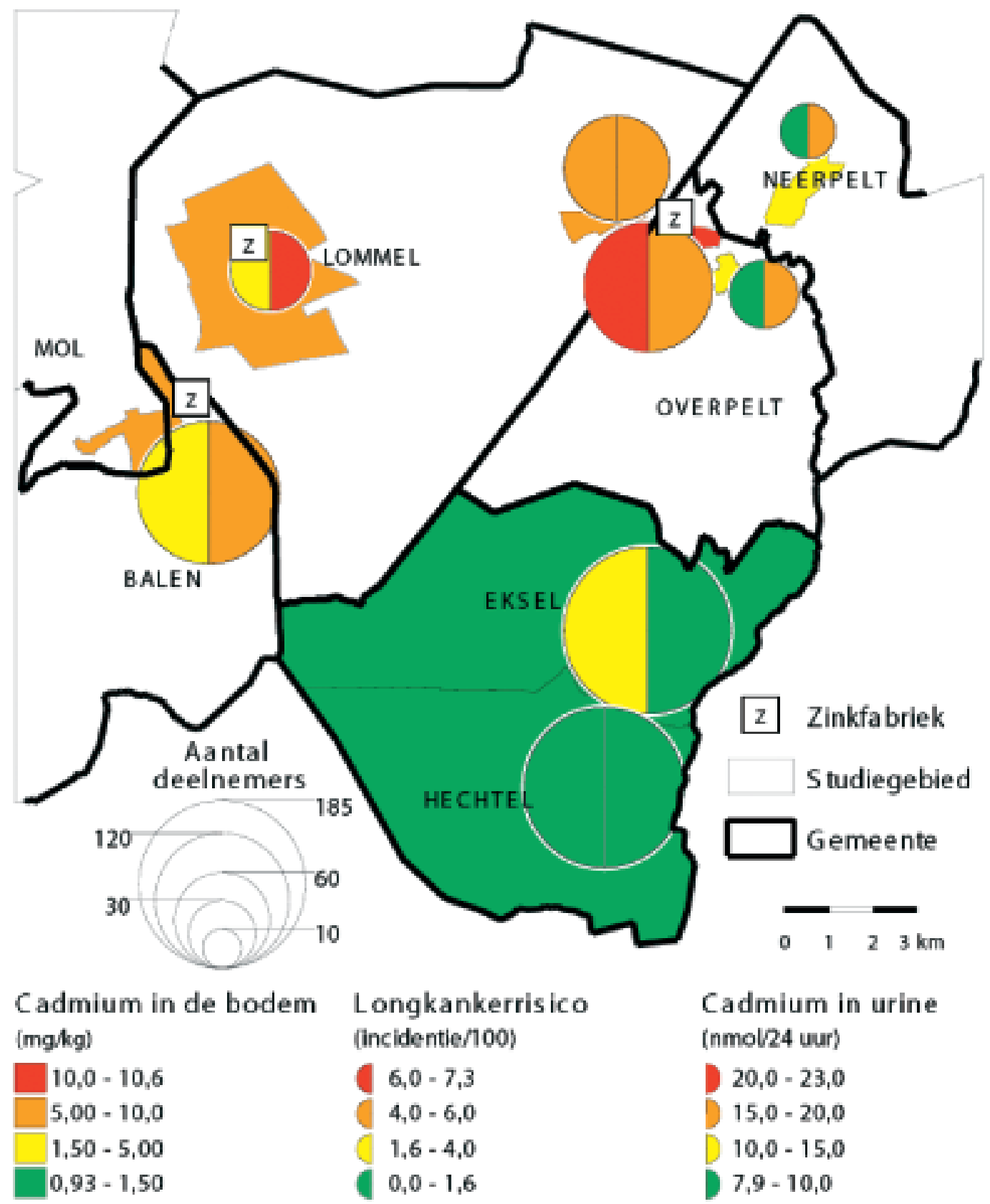

Fig. 1: Aardrijkskundige associatie tussen longkanker en de cadmiumblootstelling.

Roken beantwoordde in ons onderzoek van de interne cadmiumblootstelling aan de definitie van een verstrengelende factor (10). Inderdaad verhoogt roken zowel de kans op longkanker als de urinaire cadmiumuitscheiding. In ons onderzoek van de externe blootstelling beantwoordde roken niet meer aan deze definitie, omdat er geen enkel verband was tussen rookgewoonten enerzijds en woonplaats of de cadmiumconcentratie in de bodem anderzijds. Nochtans brachten we in alle aangepaste analysen roken in rekening zonder dat dit op enige wijze onze besluiten afzwakte.
Theoretische (14) en empirische $(15,16)$ berekeningen met of zonder aanpassing voor rookgewoonte tonen aan dat eens een ziekteverwekkende factor de kans op een aandoening met $40 \%$ of meer verhoogt (relatief risico: $\geq 1,40$ ), het in rekening brengen van roken deze pathogene factor niet meer kan herleiden tot een statistisch onbetekenisvol niveau. Het relatieve risico op longkanker geassocieerd met een verdubbeling van de urinaire cadmiumuitscheiding bedroeg 1,70 en dat geassocieerd met wonen in het verontreinigde gebied 4,17 . 

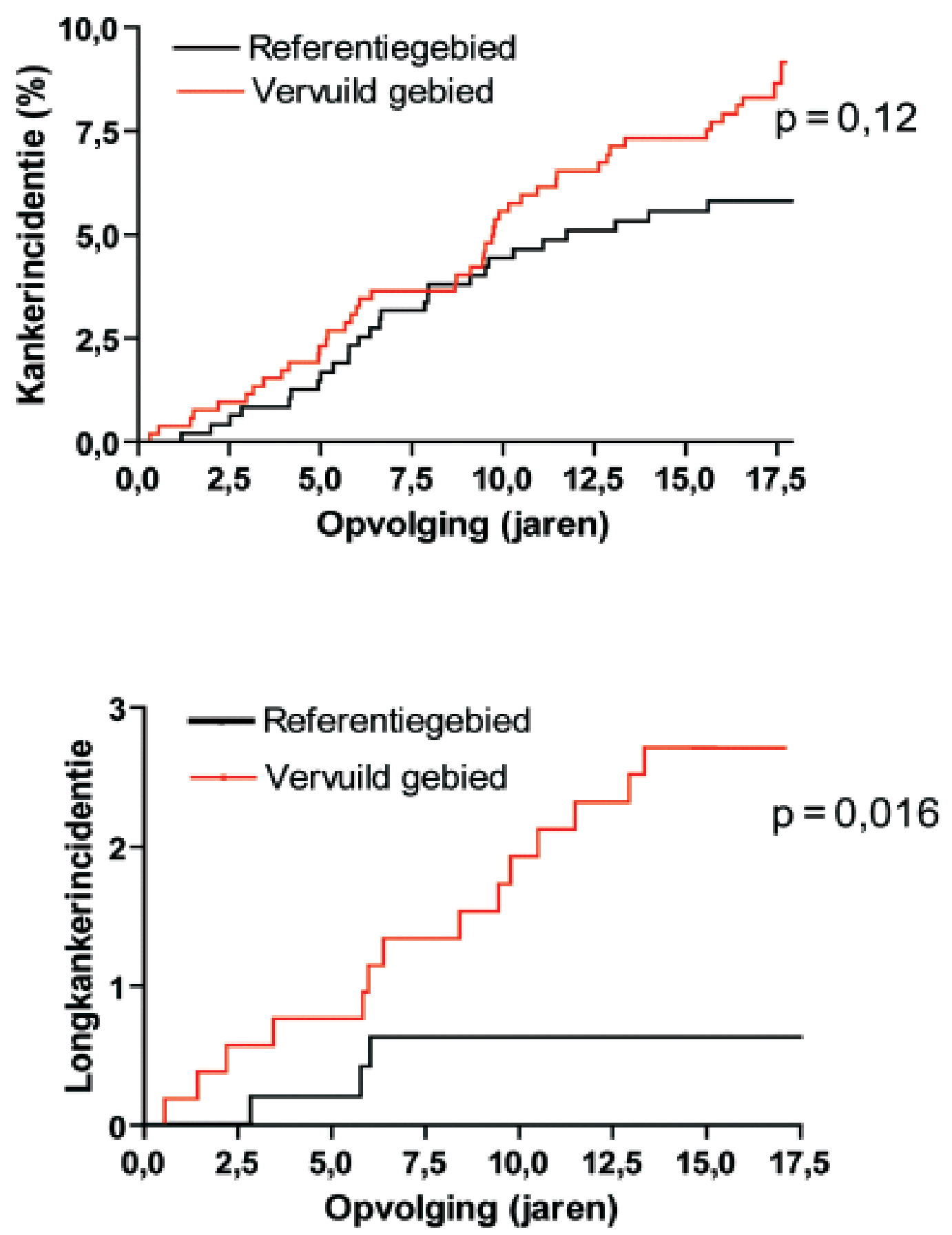

Fig. 2: Incidentie van totale kanker en longkanker in het vervuilde en het referentiegebied.

(Geactualiseerd van 30 juni 2004 tot 31 oktober 2004.)

We voerden bijkomende analysen uit om met nog grotere bewijskracht aan te tonen dat roken het verband tussen longkanker en cadmiumblootstelling niet kan verklaren. In een genestelde patiënt-versus-controleanalyse paarden we de gevallen van longkanker met twee controles van dezelfde regio volgens leeftijd ( \pm 3 jaar) en rookgewoonte bij de rekrutering. In vergelijking met de controlegroep hadden de longkankerpatiënten een uri- naire cadmiumexcretie over 24 uur, die $1,37 \mathrm{nmol}$ hoger was. Het $95 \%$-BI ging van 0,87 tot $2,40(p=0,002)$. We verkregen een vergelijkbare uitkomst met een permutatieprocedure, die geen normale distributie van de urinaire cadmiumuitscheiding veronderstelt.

In verdere aangepaste multipele analysen brachten we roken in rekening als een tijdsafhankelijke variabele, om rekening te kunnen houden met de veranderingen in het 
rookgedrag tijdens het vervolgonderzoek. Tijdsafhankelijke correctie voor rookgedrag deed niets af aan het verband tussen longkanker en de interne of externe cadmiumblootstelling.

\section{Kritiek}

Uw bevindingen worden niet bevestigd door een ecologische analyse van het Limburgs Kankerregister die geen hogere incidentie van longkanker meldde in de gemeenten waar de productie van cadmium en zink had plaatsgevonden.

\section{Antwoord}

De eenheid van analyse in een ecologisch onderzoek, zoals het Limburgs Kankerregister, is de bevolking van een geografische of administratieve eenheid (17-19). Ecologische studies zijn louter beschrijvend, maar trachten toch hun resultaten oorzakelijk te duiden in verband met een pathogene blootstelling. In feite betreft het een ecologische valkuil, die onterecht in verband gebracht wordt met een cohortenstudie. De getrapte gegevensverzameling en het beschrijven van verbanden op een zuiver collectieve basis vormen de achilleshiel van ecologische studies. Het Limburgs Kankerregister heeft geen informatie over de individuele lichaamsbelasting met cadmium, noch over de individuele verstrengelende factoren, zoals rookgewoonte. Ecologische studies zijn bovendien gevoelig voor migratie $(17,19)$, bijvoorbeeld de vestiging van gegoede Nederlanders in Noord-Limburg. Men gaat ervan uit dat de cadmiumblootstelling de afbakening van administratieve eenheden, bijvoorbeeld gemeentegrenzen, precies volgt. Op de hiërarchische ladder van wetenschappelijke bewijskracht nodig om causale verbanden aan te tonen, staan ecologische studies op de onderste trede. Ze kunnen enkel hypothesen genereren, die vervolgens in prospectief onderzoek met individuele metingen van effect, blootstelling en verstrengelende factoren moeten worden bevestigd of ontkracht.

Onze studie staat het dichtst bij een gerandomiseerd experiment, beantwoordt aan alle vereisten van een prospectief onderzoek, en onderzocht op het individuele niveau het verband tussen het optreden van ziekte, biomarkers van inwendige blootstelling en metingen van uitwendige blootstelling, hierbij rekening houdend met verstrengelende factoren. Wij kenden de medische voorgeschiedenis van iedere deelnemer. We hielden er voorts rekening mee dat pneumoconiose en silicablootstelling mogelijke risicofactoren voor longkanker vormen (20). Omdat we de medische en professionele voorgeschiedenis van individuele deelnemers kenden, konden we mijnwerkers van de berekeningen uitsluiten. Ons onderzoek staat op de bovenste sport van de ladder van causale bewijskracht. Wie ten onrechte verbanden op het collectieve niveau of het ontbreken van dergelijke verbanden doortrekt naar het individuele niveau, loopt vast in de zogenaamde ecologische valkuil.

\section{Kritiek}

Het rekruteren van families leidt tot clusters van hoge blootstelling en daarom ook tot een overschatting van het effect.

\section{Antwoord}

In onze publicatie in The Lancet Oncology hadden leden van eenzelfde gezin verschillende waarden voor de biomarkers van blootstelling aan cadmium en arsenicum. We vonden geen groepering van longkankergevallen binnen hetzelfde gezin.

SUDAAN (Research Triangle Institute in Cary, NC, VS) is een statistisch softwarepakket, dat toelaat gecorreleerde gegevens te analyseren. Gebruikmakend van dit pakket herhaalden we onze multipele aangepaste analysen, waarbij we niet alleen rekening hielden met geslacht, leeftijd en rookgewoonte, maar ook met de groepering van gegevens binnen gezinnen. Onze resultaten veranderden nauwelijks (tabel 2). Het verder gecorrigeerd relatief risico bedroeg 1,70 (95\%-BI: 1,09-2,65; $\mathrm{p}=0,025$ ) voor een verdubbeling van de urinaire cadmiumuitscheiding en 4,17 (95\%-BI: 1,2014,$6 ; p=0,025$ ) voor wonen in het vervuilde gebied.

\section{Kritiek}

De studie gebaseerd op een bevolkingssegment gerekruteerd van 1985 tot 1989 is niet meer representatief.

\section{Antwoord}

Een prospectief onderzoek moet altijd rekening houden met de latentietijd tussen het optreden van een aandoening en de blootstelling aan de pathogene factor. Longkanker heeft een latentieperiode van verschillende tientallen jaren. De vervolgperiode moet derhalve lang genoeg zijn omdat anders niet van een echt longitudinaal onderzoek kan worden gesproken.

\section{Criteria voor causaliteit}

Epidemiologische waarnemingen, zelfs indien prospectief en gebaseerd op a priori gestelde hypothesen, bewijzen op zichzelf geen oorzakelijk verband. Om dit enigszins te verhelpen stelde Sir Austin Bradford-Hill (1897-1991) in 1965 criteria voor als leidraad om een bestaande associatie te toetsen aan zes criteria die wijzen op causaliteit, namelijk de tijdslijn, de sterkte van het verband, de aanwezigheid van een dosis-effectrelatie, de consistentie van de bevindingen, de specificiteit en de biologische plausibiliteit van de associatie (9-11).

\section{Tijdslijn}

Het causaliteitsbegrip houdt in dat de oorzaak aan het gevolg voorafgaat. In een transversaal onderzoek worden mogelijke oorzakelijke factoren en gezondheidseindpunten op hetzelfde ogenblik gemeten. 
TABEL 2

Het risico op kanker in relatie tot de inwendige en uitwendige blootstelling aan cadmium.

\begin{tabular}{|c|c|c|c|c|}
\hline \multirow[b]{3}{*}{$\begin{array}{l}\text { Alle kankers } \\
\text { (aantal gevallen/onderzochten) }\end{array}$} & \multicolumn{4}{|c|}{ Relatief risico ${ }^{1}$ (95\%-betrouwbaarheidsinterval) } \\
\hline & \multicolumn{2}{|c|}{ Totale cohorte } & \multicolumn{2}{|c|}{ Milieublootgestelden2 } \\
\hline & \multicolumn{2}{|c|}{$70 / 994$} & \multicolumn{2}{|c|}{$62 / 952$} \\
\hline Verdubbeling van de cadmiumuitscheiding & $1,31(1,03-1,65)$ & 0,026 & $1,29(1,00-1,66)$ & 0,050 \\
\hline $\begin{array}{l}\text { Verdubbeling van de cadmiumconcentratie } \\
\text { in de bodem }\end{array}$ & $1,10(0,95-1,27)$ & 0,19 & $1,08(0,93-1,26)$ & 0,29 \\
\hline Hoge versus lage blootstelling & $1,31(0,81-2,12)$ & 0,28 & $1,28(0,77-2,13)$ & 0,33 \\
\hline $\begin{array}{l}\text { Longkanker } \\
\text { (aantal gevallen/onderzochten) }\end{array}$ & \multicolumn{2}{|c|}{$19 / 994$} & \multicolumn{2}{|c|}{$15 / 952$} \\
\hline Verdubbeling van de cadmiumuitscheiding & $1,70(1,13-2,57)$ & 0,011 & $1,73(1,09-2,72)$ & 0,019 \\
\hline $\begin{array}{l}\text { Verdubbeling van de cadmiumconcentratie } \\
\text { in de bodem }\end{array}$ & $1,57(1,11-2,24)$ & 0,012 & $1,49(1,04-2,14)$ & 0,032 \\
\hline Hoge versus lage blootstelling & $4,17(1,21-14,4)$ & 0,024 & $3,58(1,00-12,7)$ & 0,049 \\
\hline
\end{tabular}

Een longitudinaal onderzoek, zoals het onze, houdt in dat bij de aanvang informatie wordt verzameld over mogelijke oorzakelijke factoren en dat personen die het ziekte-eindpunt op dat ogenblik al hebben bereikt, worden uitgesloten. Alle andere personen worden dan opgevolgd voor een periode die rekening houdt met de latentietijd van de vermoedelijke oorzakelijke factor. Uiteindelijk wordt nagegaan of de incidentie van ziekte geassocieerd is met deze factor.

Maar ook in een longitudinaal cohortonderzoek is het mogelijk dat op het moment waarop de blootstelling aan de risicofactoren wordt gemeten, reeds een presymptomatisch stadium van de aandoening aanwezig is. Toch voorkomt longitudinaal onderzoek vaak typische fouten eigen aan controle-versus-patiëntstudies. Waarnemers zullen in dergelijke studies gezonde en zieke personen vaak anders bekijken. Bovendien kunnen patiënten en controlepersonen hun vragenlijsten met een andere vooringenomenheid invullen.

\section{Sterkte van het verband}

De waarschijnlijkheid van een oorzakelijk verband neemt toe met de sterkte van het verband tussen een aandoening en een mogelijke uitlokkende factor, alsook met het in rekening brengen van een groter aantal mogelijke verstrengelende elementen. De meer dan viervoudige toename van het longkankerrisico in het verontreinigde in vergelijking met het referentiegebied wijst op een sterk verband, te meer omdat we rekening hielden met geslacht, leeftijd, rookgewoonte en mogelijke blootstelling aan arsenicum. Tevens vonden we met aanpassing voor dezelfde verstrengelende factoren een toename met $70 \%$ van het longkankerrisico voor een verdubbeling van de urinaire cadmiumuitscheiding, een index van de levenslange blootstelling.

\section{Dosis-effectrelatie}

Wanneer een mogelijk uitlokkende factor oorzakelijk is, neemt de waarschijnlijkheid van een effect op de gezondheid toe met de intensiteit van de blootstelling. Naast het bovenvermelde continue verband tussen de incidentie van longkanker en de urinaire cadmiumuitscheiding, berekenden we ook het risico per derde van de verdeling van de cadmiumuitscheiding over 24 uur relatief tegenover dat in de hele cohorte.

Met aanpassingen voor geslacht, leeftijd en rookgewoonte vonden we een lineaire toename van de waarschijnlijkheid van longkanker van het laagste $(0,38)$ over het middelste $(1,39)$ tot het hoogste derde $(1,90)$.

\section{Consistentie}

Consistentie betekent dat verschillende studies of het onderzoek van verschillende segmenten van eenzelfde bevolking eenduidig hetzelfde verband tussen een gezondheidseffect en een mogelijke uitlokkende factor in het licht stellen. Onze studieresultaten zijn een primeur op het niveau van een algemene bevolking blootgesteld aan cadmium via het leefmilieu. Nochtans zijn ze in de lijn met de langetermijnopvolgingsresultaten van grote 
arbeiderscohorten (5). Onze bevindingen zijn ook consistent met experimenteel onderzoek dat cadmium aan fysiologisch relevante concentraties het DNA-herstel afremt $(6,7)$.

Onze studie heeft ook een hoge graad van interne consistentie. Het longkankerrisico nam toe zowel met de uitwendige als de inwendige blootstelling, respectievelijk weerspiegeld door de cadmiumconcentratie in de bodem en door de urinaire cadmiumuitscheiding over 24 uur. Uitsluiten van 42 op het werk blootgestelde arbeiders veranderde onze besluiten niet. Deze 42 mannen hadden, in vergelijking met mannen enkel blootgesteld via het leefmilieu, een longkankerrisico dat 3,23 maal hoger was (95\%-BI: 1,00-10,8; p = 0,05).

\section{Specificiteit}

Verschillende pathogene factoren kunnen eenzelfde aandoening uitlokken. Naarmate meer uitlokkende elementen in rekening gebracht worden, neemt de waarschijnlijkheid van een oorzakelijk verband toe. Naast cadmium, zijn roken en blootstelling aan arsenicum gekende risicofactoren voor longkanker. Onze op verschillende wijzen voor roken aangepaste analysen, zoals uiteengezet in het vorige hoofdstuk, deden het verband tussen longkanker en de cadmiumblootstelling niet verzwakken tot een statistisch onbetekenisvol niveau.

We maten ook de urinaire arsenicumuitscheiding bij $74 \%$ van onze cohorte. We extrapoleerden de arsenicumblootstelling bij de overige $26 \%$ op basis van geslacht, leeftijd en woonplaats. We konden geen synergetisch effect van cadmium en arsenicum op het longkankerrisico in het licht stellen. Rekening houdend met cadmium, voorspelde arsenicum het longkankerrisico niet. We kunnen echter niet met zekerheid uitsluiten dat de blootstelling aan cadmium gepaard ging met co-expositie aan andere kankerverwekkende stoffen, waaronder andere toxische metalen.

\section{Plausibiliteit}

Alle cellen van het lichaam hebben beschermingsmechanismen, die een voortdurende strijd aanbinden tegen de inductie van mutaties, cellulaire disfunctie, en maligne transformatie, waaronder DNA-herstel, celcyclusregulatie en apoptosis (21). DNA-herstel is nodig om cellen te beschermen tegen de schade, die optreedt ten gevolge van het normaal functioneren van de cel. Een remming van de DNA-herstelcapaciteit treedt op bij cadmiumconcentraties, die voorkomen in de longen van blootgestelde personen $(6,7)$. Het concept dat cadmium door het verlagen van de DNA-herstelactiviteit resulteert in een verhoging van het aantal gefixeerde mutaties voor een bepaalde blootstelling aan mutagene stoffen werd ook bevestigd door Godschalk en collega's. In navelstrengbloed vonden deze onderzoekers een associatie tussen het aantal gefixeerde mutaties per DNA-adduct en de cadmiumconcentratie (22). Bovendien vermoeden wij dat genetisch geprogrammeerde verschillen in het
DNA-herstellingsvermogen de individuele gevoeligheid tegenover kankerverwekkende polluenten beïnvloeden.

\section{Preventiemaatregelen ter vermindering van de blootstelling}

De gezondheidseffecten die optreden ten gevolge van blootstelling aan cadmium, vereisen preventiemaatregelen om de transfer van dit cumulatief toxisch metaal vanuit het milieu naar de mens zo veel mogelijk af te remmen.

\section{Transfer via ingeademde lucht}

Van het met de lucht ingeademde cadmium wordt ongeveer de helft opgenomen via de longalveoli (23). Een sigaret bevat ongeveer $1 \mu \mathrm{g}$ cadmium. Een voor de hand liggende preventiemaatregel, die ook getuigt van een gezonde levensstijl, is niet te roken en ook passieve blootstelling aan tabaksrook te vermijden.

\section{Zwevend en neervallend stof}

Tot in het midden van de jaren tachtig bevatte het zwevende en neervallende stof in de omgeving van de zinkovens grote hoeveelheden vervuilende substanties, waaronder cadmium en andere metalen (24). De afmetingen van de ingeademde stofdeeltjes bepalen mede hoeveel cadmium in het lichaam wordt opgenomen. Het trilhaarepitheel en het mucociliair transport in de bovenste en onderste luchtwegen voert stofdeeltjes met een aerodynamische diameter groter dan $10 \mu \mathrm{m}$ naar de keelholte $(23,25)$. Nadat ze doorgeslikt werden, komen deze terecht in het maagdarmkanaal, waar de cadmiumabsorptie weinig effectief is. Stofdeeltjes met een diameter van minder dan $10 \mu \mathrm{m}$ dringen gemakkelijker door tot de alveoli. Macrofagen nemen de stofdeeltjes op en brengen op deze wijze cadmium doorheen de alveolaire barrière in de bloedstroom.

Sinds 1990 deden doorgedreven verbeteringen in de raffinage van zink en cadmium de emissies sterk afnemen. Het meetnet van de Vlaamse Milieumaatschappij toonde aan dat op dit ogenblik de emissie van cadmium in het verontreinigde studiegebeid onder de norm van de Wereldgezondheidsorganisatie lag $\left(<5 \mathrm{ng} / \mathrm{m}^{3}\right)$, maar dat deze laatste nog steeds overschreden werd in Beerse, vlakbij de Nederlandse grens.

\section{Opwaaiend stof}

Stof dat opwaait van een historisch vervuilde bodem is met cadmium besmet en geeft aanleiding tot een aanhoudende secundaire verontreiniging van het leefmilieu (24). Onderzoek van stofkorrels klevend aan dennennaalden en berkenbladeren toonde aan dat de wind de verontreiniging met $3 \mathrm{~km}$ kan verplaatsen. Röntgenstralendiffractie van deze stofkorrels wees op een dominantie van zink en zwavel. Dergelijke partikels kunnen enkel afkomstig zijn van de ertsen die als bron dienden voor de zinkproductie en die naast zink ook cadmium bevatten (26). Het opwaaiende stof kan zich ook vastzetten op landbouwgewassen. 
Verder onderzoek moet nog uitmaken in welke mate opwaaiend stof bijdraagt tot de blootstelling van de mens aan cadmium. Deze stofpartikels hebben overwegend een grotere diameter, waardoor ze minder gemakkelijk in de longalveoli doordingen, maar eerder het maagdarmkanaal bereiken. Anderzijds blijft het mogelijk dat cadmium ook via het slijmvlies van de nasofarynx en de bronchi in de bloedbaan kan overgaan (27).

Aangepaste beplanting, het aanbrengen van een duurzame verharding of - waar nodig - afgraving zijn maatregelen die het opwaaien van stof van een verontreinigde grond voorkomen.

\section{Stof in de woning}

Met cadmium gecontamineerd stof dat van buiten doordringt tot in de woning en dan binnenshuis circuleert, vormt een relatief belangrijke bron van cadmiumblootstelling. Het gebruik van met cadmium gecontamineerde zinksintels is in Limburg wijdverspreid voor de verharding van wegen en opritten en zorgt voor een blijvende pollutie van de huizen met cadmiumstof dat via schoeisels of via de verluchting naar binnen wordt gebracht.

We verzamelden bij 473 deelnemers aan ons onderzoek die in het vervuilde of het controlegebied verbleven, het binnenhuisstof op schaaltjes die we voor 3 maanden in hun slaapkamers achterlieten (28). Per 3 maanden bedroeg de cadmiumdepositie via het huisstof gemiddeld $0,29 \mathrm{ng} / \mathrm{cm}^{2}$ in het verontreinigde gebied en $0,12 \mathrm{ng} / \mathrm{cm}^{2}$ in het referentiegebied $(p<0,01)$. We vonden een positief verband tussen de cadmiumneerslag in de woningen en de cadmiumconcentratie in de bodem $(\mathrm{r}=0,52$; $\mathrm{p}=$ 0,0001 ). Voor een tweevoudige toename van de cadmiumbelasting via het huisstof steeg de urinaire cadmiumuitscheiding van de huisbewoners met $3 \%$, wat ongeveer evenveel was als de toename gepaard gaande met de cadmiumconcentratie in lokaal geteelde groenten (28).

De meest gangbare opvatting is dat de voedselketen de belangrijkste bron van cadmiumblootstelling is. We geloven op basis van onze recente gegevens dat het risico van blootstelling via verontreinigd huisstof minstens even groot is (28). Deze hypothese gaat waarschijnlijk niet alleen op voor het studiegebied, maar wereldwijd waarschijnlijk ook voor vele andere regio's, waar de bodem met cadmium vervuild is. Bovendien blijft het belang van de kwantitatief belangrijkste blootstellingsroute ondergeschikt aan het bereiken van de kritieke cadmiumconcentratie, die in doelorganen aanleiding geeft tot gezondheidschade. Dit principe is uitermate belangrijk voor de inademing van met cadmium vervuild stof, die de long tezelfdertijd een orgaan maakt dat betrokken is in de opname van cadmium, maar ook een rechtstreeks mikpunt van DNA-schade.

Om besmetting via het huisstof te voorkomen, stellen we naast bodemsanering ook een goede stofcontrole voor in de woning. Aan te raden voorzorgsmaatregelen zijn onder meer:

- Het vervangen van tapijten en matten door een gladde en gemakkelijk met vocht te onderhouden vloerbedekking, zoals linoleum, kurk, tegels of geplastificeerd parket.
- Het plaatsen in een afgesloten kast van voorwerpen die stof aantrekken. Echte stofhaarden zijn droogbloemen, pluchen of met pluimen gevuld speelgoed, veren, dierenhuidharen, en boeken.

- Het kiezen voor houten zitmeubilair en zetels waarvan het oppervlak bekleed is met kunststof of leder in plaats van textiel.

- Het regelmatig wassen van gordijnen.

- Het vervangen van de stofzuiger door bezem of borstel, vochtige doeken, statische plumeaus, of vloerzwabbers met een oliehoudend doekje.

\section{Transfer via gecontamineerde voeding}

Van het cadmium dat de mens bereikt via het maagdarmkanaal, bereikt bij normale ijzerstatus ongeveer $5 \%$ de bloedstroom.

\section{Putwater}

Bij de lage zuurtegraad $(\mathrm{pH})$ eigen aan de zanderige bodem in het studiegebied loogt regen cadmium uit naar het ondiepe grondwater (29). Voor particuliere waterwinning worden deze ondiepe grondwaterlagen aangeboord. In Noord-Limburg bevat het grondwater veel cadmium. De inwoners van deze streek moeten daarom putwater vervangen door leidingwater, zowel om te drinken als bij het wassen of bereiden van voedingsmiddelen. Dit geldt ook voor het vullen van kinderbadjes.

\section{Groenten geteeld op verontreinigde grond}

Gewassen nemen meer cadmium op naarmate in de teeltgrond de metaalconcentratie hoger is en de $\mathrm{pH}$ en het aandeel van organische materie lager zijn. De kritieke bodemconcentratie, waarbij overschrijdingen van de norm kunnen optreden, in het bijzonder voor bladgewassen die veel cadmium opnemen, bedraagt $1,2 \mathrm{mg}$ cadmium per kilogram grond.

Prei $(1,58$ vs. $0,67 \mathrm{mg} / \mathrm{kg})$ en selderij $(2,43$ vs. $0,68 \mathrm{mg} / \mathrm{kg}$ ) gewonnen in het vervuilde gebied waren meer met cadmium gecontamineerd dan deze gewonnen in het controlegebied $(2,28)$. Het telen van bladgewassen op vervuilde grond moet sterk worden ontraden (24). Normoverschrijding komt ook vaak voor in worteltjes en schorseneren. Bonen en erwten, aardappelen, en vooral komkommers en pompoenen nemen van nature minder gemakkelijk cadmium op en stellen dus doorgaans minder problemen. De $\mathrm{pH}$ van de bodem door bekalking hoog houden $(\geq 6.5$ ) en de grond aanreiken met organisch materiaal zijn twee maatregelen, die de opname van cadmium door gewassen in belangrijke mate verminderen (24).

\section{Transfer via picagedrag}

Na spel, sport of arbeid op besmette terreinen kan met cadmium gecontamineerd stof op de handen blijven kleven. Grondig wassen van de handen verwijdert dit stof. Deze eenvoudige hygiënische maatregel voorkomt dat, 
wanneer met de handen wordt gegeten, het cadmium langs de mond en het maag-darmkanaal de bloedbaan bereikt. Om dezelfde reden moet men vermijden dat kinderen, in het bijzonder peuters, spelen op verontreinigde terreinen. Jonge kinderen brengen het vuil dat ze van de grond oprapen, evenals hun vuile handen, naar de mond, wat tot een verhoogde cadmiumblootstelling kan leiden.

\section{Noodzaak tot verder onderzoek}

Of het picagedrag van kinderen wezenlijk bijdraagt tot de blootstelling aan cadmium werd nog nooit wetenschappelijk onderzocht. Dit zou kunnen gebeuren door de hoeveelheid cadmium te meten die kleeft op de handen van kleuters. In 1980 voerden we een dergelijke studie uit bij schoolgaande kinderen, die woonden in de omgeving van de loodsmelter te Hoboken (30).

Om de maatregelen die de Vlaamse regering op 13 februari 2006 afkondigde te toetsen, is het aangewezen om bij bodemsaneringen in de omgeving van de vroegere bedrijven de cadmiumbelasting bij de omwonenden te meten zowel vóór als enkele jaren na de remediëring. Dergelijk beleidsvoorbereidend onderzoek zou de gelegenheid bieden om na te trekken of deze kostbare ingreep het blootstellingsrisico effectief vermindert. Onze cohorte zou hiervoor uitermate geschikt zijn. We beschikken al over biomarkers van blootstelling voor de perioden 1985-1989 en 1990-1995 (31). Van 1998 tot 2004 verzamelden wij bij een 500-tal personen urine- en bloedmonsters, waarop biomarkers van blootstelling en effect nog kunnen gemeten worden. Longitudinaal onderzoek toonde aan dat van 1985 tot 1995 de cadmiumconcentratie in het bloed, een biomarker van recente blootstelling, afnam met $29,6 \%$. De cadmiumuitscheiding over 24 uur in de urine, een index van levenslange blootstelling, daalde echter maar met $15,2 \%$. Om het verdere beleid te ondersteunen is het nodig te weten of de preventiemaatregelen in het verontreinigde gebied en het bodemsaneringsbeleid deze seculiere trends al dan niet versterken. We vonden dat de hoeveelheid cadmium in het neervallende huisstof de interne blootstelling voorspelde. Verder onderzoek van het cadmiumgehalte in de fractie van fijn huisstof met een diameter kleiner dan 2,5 $\mu \mathrm{m}$ is aangewezen.

Grote delen van België zijn in hoge mate verontreinigd door cadmium. Al bij de aanvang van het CadmiBel-onderzoek nam de Waalse overheid de optie om over de taalgrens geen wetenschappelijk onderzoek naar verontreiniging met cadmium te ondersteunen. In Vlaanderen bestaat een betere inventaris van de bodemverontreiniging, maar in verschillende regio's waar de grond sterk met cadmium vervuild is, blijft het blootstellingsniveau van de omwonenden ongedocumenteerd. Dit is onder meer het geval te Beerse, waar de luchtverontreiniging onaanvaardbaar hoog blijft, en te Kruibeke, waar de cadmiumconcentratie in de bodem langs de Scheldeoever oploopt tot $9 \mathrm{ppm}$, vermoedelijk ten gevolge van pollutie afkomstig van de metallurgie aan de overzijde van de rivier.

\section{Besluit}

Onze bevindingen over de gezondheidseffecten van milieuverontreiniging met cadmium hebben belangrijke implicaties $(1-3,8,12)$. Het is dringend nodig om wereldwijd de blootstelling aan cadmium terug te dringen (32).

In de context van onze studieresultaten is het absoluut noodzakelijk dat in dichtbevolkte streken, zoals Vlaanderen, de luchtconcentratie aan cadmium voldoet aan de norm $\left(<5 \mathrm{ng} / \mathrm{m}^{3}\right)$, die de Wereldgezondheidsorganisatie vastlegde op basis van extrapolaties vanuit dierproeven en waarnemingen in arbeiderscohorten (33). Momenteel beantwoorden de cadmiumwaarden voor zwevend stof in het bestudeerde gebied aan deze normen. De bodem blijft er echter nog voor eeuwen met cadmium vervuild. Ons onderzoek suggereert dat mede hierdoor het huisstof een blijvende bron van blootstelling blijft (29). In een andere Vlaamse gemeente, namelijk te Beerse, wordt de cadmiumnorm nog steeds overschreden met in 2004 een daggemiddelde van $27 \mathrm{ng} / \mathrm{m}^{3}$ en een maximale waarde van $323 \mathrm{ng} / \mathrm{m}^{3}$ (meetpost 0BE01; zie http://www.vmm.be).

Uit meer dan 20 jaar ervaring leerden we dat de criteria waarmee opiniemakers wetenschappelijk onderzoek naar de volksgezondheid beoordelen losser worden, wanneer wij een gezondheidseffect konden terugvoeren naar milieufactoren. Zelfs wanneer het methodologische kader ongemeen sterk was, stak scepsis dan zeer vlug de kop op.

Studies uitgevoerd met dezelfde methodologie als ons huidig longitudinaal onderzoek (8), leverden de eerste wetenschappelijke bewijzen voor het verband tussen myocardinfarct en cholesterol (34) of tussen spina bifida en foliumzuurdeficiëntie (35). Klinische studies op basis van loting bevestigden nadien deze relaties $(34,35)$. Gerandomiseerde interventiestudies in verband met milieugeneeskundige problemen stellen echter praktische en ethische problemen. Longitudinale studies met opvolging van gezondheidseffecten en metingen van biomarkers van effect en blootstelling in verontreinigde gebieden met en zonder interventie zijn de enige mogelijke weg voorwaarts.

\section{Mededelingen}

\section{Belangenconflict}

In het kader van de EU Chemicals Bureau Existing Substances Programme was prof. H.A. Roels lid van het wetenschappelijk reviewerspanel voor het „Voluntary Risk Assessment Report on Lead and Lead Compounds" dat werd opgesteld door de International Lead Zinc Research Organization (ILZRO) (Research Triangle Park, NC, USA), de European Bio-Research Consultants (EBRC Consulting GmbH, Hannover, Germany), en de Lead Development Association International (LDAint, London, UK). De andere auteurs hebben geen belangenconflicten.

\section{Financiële ondersteuning en dankwoord}

ILZRO ondersteunde gedeeltelijk de opvolging van onze cohorte van 25 januari 1990 tot 24 februari 1994. De gemeente Hechtel-Eksel huisvest het lokale onderzoekscentrum in Noord-Limburg en leverde logistieke steun.

Sandra Covens, Hanne Truyens, Marie-Jeanne Jehoul en Renilde Wolfs hielpen bij de redactie van dit manuscript. 


\section{Abstract}

Lung cancer and environmental exposure to cadmium: a reply to the critique and evaluation of causality

We investigated whether the risk of lung cancer is related to environmental exposure to cadmium. From 1985-1989 we randomly recruited 994 subjects from areas with low and high exposure to cadmium. We measured their 24-hour urinary cadmium excretion, an index of lifelong exposure, as well as the cadmium concentration in the soil of their kitchen gardens.

The cadmium concentration in the soil ranged from 0.8 to $17.0 \mathrm{mg} / \mathrm{kg}$. The 24-hour urinary cadmium excretion averaged $12.3 \mathrm{nmol}$ in residents of the polluted area, compared to $7.7 \mathrm{nmol}$ in the reference area $(p<0.0001)$. During 17.2 years (median) of follow-up, 53 fatal and 20 non-fatal cancers occurred, of which 18 and 1 were lung cancers (outcome updated until 31 October 2004). The hazard ratios for lung cancer adjusted for sex, age and smoking, were $1.70(1.13-2.57 ; p=0.011)$ for a doubling of the urinary cadmium excretion, 4.17 (1.21-14.4; $p=0.024$ ) for residing in the high versus low exposure area, and $1.57(1.11-2.24 ; p=0.012)$ for a doubling of the cadmium concentration in the soil.

In the first part of the present overview, we summarized our findings which were previously published in English. Next, we report the results of additional analyses, which we executed in response to the critical comments on our primary study. We also verified our primary and additional study results according to the Bradford-Hill criteria to detect a causal association.

Finally, we reviewed possible mechanisms underlying the association between lung cancer and exposure to cadmium as well as the preventive measures which can be implemented in areas environmentally polluted by cadmium.

\section{Literatuur}

1. Buchet JP, Lauwerys R, Roels H, et al. Renal effects of cadmium body burden of the general population. Lancet 1990; 336: 699-702.

2. Staessen JA, Lauwerys RR, Ide G, Roels HA, Vyncke G, Amery A. Renal function and historical environmental cadmium pollution from zinc smelters. Lancet 1994; 343: 1523-1527.

3. Staessen JA, Roels HA, Emelianov D, et al. Environmental exposure to cadmium, forearm bone density, and risk of fractures: prospective population study. Public Health and Environmental Exposure to Cadmium (PheeCad) Study Group. Lancet 1999; 353: 1140-1144.

4. International Agency for Research on Cancer. Cadmium and cadmium compounds. Lyon: France: International Agency for Research on Cancer, World Health Organization, 1993.

5. Verougstraete V, Lison D, Hotz P. Cadmium, lung and prostate cancer: a systematic review of recent epidemiological data. J Toxicol Environ Health 2003; 6: 227-255.
6. Jin YH, Clark AB, Slebos RJ, et al. Cadmium is a mutagen that acts by inhibiting mismatch repair. Nat Genet 2003; 34: 326329.

7. Hartwig A, Asmuss M, Ehleben I, et al. Interference by toxic metal ions with DNA repair processes and cell cycle control: molecular mechanisms. Environ Health Perspect 2002; 110: 797-799.

8. Nawrot T, Plusquin M, Hogervorst J, et al. Environmental exposure to cadmium and risk of cancer: a prospective populationbased study. Lancet Oncol 2006; 7: 119-126.

9. HiLl AB. The environment and disease: Association or causation? Proc Soc Med 1965; 58: 295-300.

10. Rothman KJ. Epidemiology. An introduction. New York: Oxford University Press, 2002.

11. Rothman KJ, Greenland S. Causation and causal inference in epidemiology. Am J Public Health 2005; 95 Suppl 1: S144-S150.

12. Staessen JA, Buchet JP, Ginucchio G, et al. Public health implications of environmental exposure to cadmium and lead: an overview of epidemiological studies in Belgium. Working Groups. J Cardiovasc Risk 1996; 3: 26-41.

13. Lauwerys R, Amery A, Bernard A, et al. Health effects of environmental exposure to cadmium: objectives, design and organization of the Cadmibel Study: a cross-sectional morbidity study carried out in Belgium from 1985 to 1989. Environ Health Perspect 1990; 87: 283-289.

14. Axelson O, SteEnland K. Indirect methods of assessing the effects of tobacco use in occupational studies. Am J Ind Med 1988; 13: 105-118.

15. Blair A, Hoar SK, Walrath J. Comparison of crude and smoking-adjusted standardized mortality ratios. J Occup Med 1985; 27: $881-884$

16. Siemiatycki J, Wacholder S, Dewar R, Cardis E, Greenwood C, RiCHARDSON L. Degree of confounding bias related to smoking, ethnic group, and socioeconomic status in estimates of the associations between occupation and cancer. J Occup Med 1988; 30: 617-625.

17. Morgenstern H, Thomas D. Principles of study design in environmental epidemiology. Environ Health Perspect 1993; 101 Suppl 4: 23-38.

18. GRimes DA, Schulz KF. Descriptive studies: what they can and cannot do. Lancet 2002; 359: 145-149.

19. JARUP L, BEST N. Editorial comment on Geographical differences in cancer incidence in the Belgian Province of Limburg by Bruntinx and colleagues. Eur J Cancer 2003; 39: 1973-1975.

20. International Agency for Research on Cancer. IARC monographs on the evaluation of carcinogenic risk to humans. Volume 68: Silica, some silicates, coal dust and para-aramid fibers. Lyon: IARC, 1997.

21. Nawrot T, Den Hond E, Staessen JA. Milieutoxicologische metingen, een synopsis voor de algemene practicus. Deel 2: biomonitoring van polycyclische aromatische koolwaterstoffen en benzeen, een moleculair-epidemiologische benadering. Tijdschr Geneesk 2002; 58: 283-290.

22. Godschalk R, Hogervorst J, Albering H, et al. Interaction between cadmium and aromatic DNA adducts in hprt mutagenesis during foetal development. Mutagenesis 2005; 20: 181-185.

23. Nawrot T, Den Hond E, Staessen JA. Milieutoxicologische metingen, een synopsis voor de algemene practicus. Deel 3: toxicologie en biomonitoring van lood en cadmium. Tijdschr Geneesk 2002; 58: 427-434.

24. Staessen JA, Roels H, Vangronsveld J, et al. Preventiemaatregelen voor bodemverontreiniging met cadmium. Tijdschr Geneesk 1995; 51: 1387-1395.

25. Nawrot T, Den Hond E, Staessen JA. Milieutoxicologische metingen, een synopsis voor de algemene practicus. Deel 1: basisprincipes en biomonitoring in de toxicologie. Tijdschr Geneesk 2002; 58: 136-142.

26. VAngronsveld J, Van Assche F, Clussters H. Reclamation of a bare industrial area contaminated by non-ferrous metals: in situ metal immobilization and revegetation. Environ Pollut 1995; 87: 51-59.

27. Jarup L, BERglund M, Elinder CG, NordBERG G, VAhTER M. Health effects of cadmium exposure - a review of the literature and a risk estimate. Scand J Work Environ Health 1998; 24 Suppl 1: 1-51.

28. Hogervorst J, Plusquin M, Vangronsveld J, et al. House dust as possible route of environmental exposure to cadmium and lead in the adult general population. Environ Res 2007; 130: 30-37. 
29. Staessen JA, Vyncke G, Lauwerys RR, et al. Transfer of cadmium from a sandy acidic soil to man: a population study. Environ Res 1992; 58: 25-34.

30. Roels HA, Buchet JP, Lauwerys RR, et al. Exposure to lead by the oral and the pulmonary routes of children living in the vicinity of a primary lead smelter. Environ Res 1980; 22: 81-94.

31. Staessen JA, Kuznetsova T, Roels HA, Emelianov D, Fagard R. Exposure to cadmium and conventional and ambulatory blood pressure in a prospective population study. Public Health and Environmental Exposure to Cadmium Study Group. Am J Hypertens 2000; 13: 146-156.
32. NORDBERG GF. Lung cancer and exposure to environmental cadmium. Lancet Oncol 2006; 7: 99-101.

33. European Commission. Working Group On Arsenic, Cadmium And Nickel Compounds. Ambient air pollution by arsenic, cadmium and nickel compounds. Position paper. Luxembourg: European Commission, 2000.

34. Kannel WB, Castelli WP, Gordon T, McNamara PM. Serum cholesterol, lipoproteins, and the risk of coronary heart disease. The Framingham study. Ann Intern Med 1971; 74: 1-12.

35. Moore LL, Bradlee ML, Singer MR, Rothman KJ, Milunsky A. Folate intake and the risk of neural tube defects: an estimation of dose-response. Epidemiology 2003; 14: 200-205. 